\title{
Aerosol in the atmosphere of the Baikal region: history and contemporary researches
}

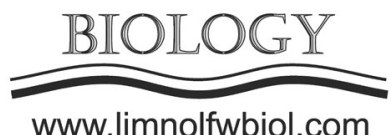

www.limnolfwbiol.com

\author{
Golobokova L.P.*®, Khodzher T.V., Obolkin V.A., Potemkin V.L., Khuriganova O.I., \\ Onischuk N.A.
}

Limnological Institute, Siberian Branch of the Russian Academy of Sciences, 3, Ulan-Batorskaya Str., Irkutsk, 664033, Russia

\begin{abstract}
The results of long-term studies (1995-2017) of the physical properties and chemical composition of atmospheric aerosol in the Baikal region are considered. These studies are important for understanding the role of the atmosphere in the formation of the chemical composition and quality of the waters of Baikal and its inflows. Over the past two decades, Limnological Institute SB RAS (Irkutsk, Russia) have conducted various joint studies of the characteristics of atmospheric aerosol with Russian and foreign groups. The chemical composition, biological component, size distribution, spatial distribution and aerosol sources over the lake were investigated. The interannual variability of the main chemical compounds in the aerosol was estimated. So, over the period studied, there was a gradual decrease observed in the concentrations of the main ions in the aerosol composition: in Irkutsk by 2.1 times, Listvyanka - by 4.0 times, at the background site of Mondy - by 3.5 times. In addition to quantitative changes, there is a change in the ratio of the main ions in the aerosol at Listvyanka site (south-west coast of Lake Baikal) and at the background site of Mondy. Upon condition of no external influences the content of the main ions in the aerosol on the surface layer of Lake Baikal is significantly lower $\left(0.33-5.2 \mu \mathrm{g} \cdot \mathrm{m}^{-3}\right)$ than during of extreme conditions $\left(2.2-5.2 \mu \mathrm{g} \cdot \mathrm{m}^{-3}\right)$. Forest fires near Baikal cause an increase of the concentrations of $\mathrm{Na}^{+}, \mathrm{K}^{+}, \mathrm{NH}_{4}^{+}, \mathrm{Cl}$, and $\mathrm{NO}_{3}^{-}$ions in Baikal aerosols. Components of soil-erosion origin ( $\mathrm{Al}, \mathrm{Fe}, \mathrm{Zn}, \mathrm{Cr}, \mathrm{Ba}$ ) dominate in the elemental composition of the aerosol. Their concentration increases during forest fires up to $1.4-6$ times at average. The flows of sulfur and nitrogen, the main acidifying components, differ in different years of observations both at the monitoring sites and over the surface of Lake Baikal.
\end{abstract}

Keywords: Atmospheric aerosol, Baikal region, Chemical composition, Fluxes, Sources

\section{A brief history of the study of atmo- spheric aerosol in the Baikal region}

Studies of the air basin of the Baikal region in the 1970s-80s were mainly focused on studying of the chemical composition of atmosphere precipitations and its role in the chemical balance of Baikal waters (Khodzher, 1983; Vetrov et al., 1985; Obolkin et al., 1990; Anokhin et al., 1991). It was shown that the long-term ingress of acid components with atmosphere precipitations and their high accumulation in the snow cover and soils of the inflows' basins of the Southern Baikal caused to a shift of the main ions balance in the waters of the Southern Baikal inflows towards an increase of content of sulfates and a decrease of content of hydrocarbonates (Sorokovikova et al., 2004; Khodzher, 2005; Obolkin et al., 2016). Studies have shown the significant role of the atmosphere in the ingress of substances on the underlying surface. Studies of atmo- spheric aerosol, one of the most dynamic components of the atmosphere, began a while later, after 1993. The areas to be studied were selected with due regard to varying degrees of anthropogenic influence (Khodzher et al., 1997a). In the 1990s - 2000s, with the participation of well-known Russian and foreign aerosol research groups, within the framework of RFBR, INTAS, ISTC projects, the «Siberian Aerosols» complex project and others, numerous field works were carried out to investigate various characteristics of atmospheric aerosol over Siberia and over Lake Baikal. The scientists of Limnological Institute (Irkutsk, Russia), of Voevodsky Institute of Chemical Kinetics and Combustion SB RAS (Novosibirsk, Russia), of Karpov Institute of Physical Chemistry (Moscow, Russia), University of Antwerp (Belgium) and Johannes Gutenberg University Mainz (Germany) they all studied in detail the composition of aerosol of various size fractions as of the size of several angstroms to the size of tens of microns (Koutsenogii et. al., 1993; Van Malderen et al., 1994; 1996). The

*Corresponding author.

E-mail address: 1g@lin.irk.ru (L.P. Golobokova) 
biological component of the Baikal aerosol was investigated, its content can reach $60-80 \%$ of the total aerosol mass. In the seasonal large particles dynamics an intense spring-summer maximum is traced due to birch pollen (in April), coniferous trees (in June and July). In the composition of the biological component also various bacteria, viruses, etc. were revealed (Mattias-Maser et al., 2000).

In 1998, three sites for the continuous monitoring of the atmosphere were established, which since 2001 were included into EANET's international network sites of acid deposition monitoring in Southeast Asia (Acid Deposition Monitoring Network in East Asia) (EANET, 2000). Precipitation and weekly aerosol samples are taken at the stations all year round. In addition to these observations of atmospheric impurities there are summertime regular researches conducted above the water area of the lake using the research vessels owned by Limnological Institute SB RAS. Spatial characteristics of chemical and physical properties of the atmospheric aerosol above the Baikal waters are analyzed. This has made it possible to estimate the mass fraction of the aerosol attributable to the submicron part $(\mathrm{d}<1 \mu \mathrm{m})$ and the coarsely dispersed fraction $(\mathrm{d}>1 \mu \mathrm{m})$. Baikal aerosol is mainly represented by small particles. Their origin greatly depends on the seasons of the year, although soil and the crust generally remain the dominant sources. High concentrations of $\mathrm{Al}, \mathrm{Ca}, \mathrm{Na}, \mathrm{Mg}, \mathrm{Cl}$ indicate the predominance of natural sources of aerosol over the lake. In the cold period of the year, due to the increase of burned combustible amount and to the degradation of the property of the atmosphere to dispel, the anthropogenic contribution to such elements as As, $\mathrm{Sb}$, Co increases (Obolkin et al., 1994; Van Malderen et al., 1994; Belan et al., 1996; Khodzher et al., 1997b). The main components of the soluble fraction of aerosols $\left(\mathrm{SO}_{4}^{2-}, \mathrm{NO}_{3} ; \mathrm{NH}^{+}, \mathrm{Ca}_{2}{ }^{+}\right.$) were identified (Khodzher et al., 1994; Golobokova et al., 2002; 2004). Using of statistical methods and the analysis of synoptic processes in the atmosphere has made it possible to separate the contribution of natural and anthropogenic sources in the composition of aerosols. Concentrations of alkali and alkaline-earth metal ions in aerosols increase when air flows from continental regions of Mongolia, sulphate and nitrate ions concentration increases when air masses are transported from industrial areas of Siberia (Golobokova et al., 2005; 2006). The researches have an important practical application since the role of the atmosphere in the formation of the chemical composition and quality of the waters of Lake Baikal and its inflows has increased in recent years.

The contribution of regional industrial centers to the atmospheric pollution of Lake Baikal was studied within a framework of the Integration Project of the SB RAS "Assessing of the anthropogenic sources impact on the Baikal region atmosphere quality based on the experimental observations by means of laser sounding and mathematical modeling methods" with the participation of the Institute of Physical Material Science of SB RAS (Ulan-Ude, Russia), V.E. Zuev Institute of Atmospheric Optics of SB RAS (Tomsk, Russia), Institute of Computational Mathematics and Mathematical
Geophysics of SB RAS (Novosibirsk, Russia). The distribution of the aerosol was investigated not only in the surface layer, but also in the upper atmosphere up to 2-3 $\mathrm{km}$ from the earth's surface (Balin et al., 2016; Obolkin et al., 2017).

This article summarizes the results of long-term observations of only one of the characteristics of atmospheric aerosol - the chemical composition of the soluble fraction of the Baikal aerosol. It is exactly that fraction of the aerosol in condition of dry precipitation and atmospheric precipitations which participates in the formation of the composition of the main water ions of the lake.

\section{Materials and methods}

Atmospheric aerosol was sampled in the near-water layer of the atmosphere above the Lake Baikal and at three sites upon the EANET international program: Irkutsk (52.3 N; 104.4 E) is a city site which characterizes an urbanized territory; Listvyanka site $(51.9 \mathrm{~N}$; 104.7 E) is a site on the southwest coast of Lake Baikal which reflects the rural area conditions; Mondy (51.6 $\mathrm{N} ; 101.0 \mathrm{E}$ ) is a background site remote from industrial centers of more than $300 \mathrm{~km}$, at an altitude of $2005 \mathrm{~m}$ above sea level in the mountainous area between the ridges of the Eastern Sayans and Khamar-Daban. In the near-water layer of the atmosphere of Lake Baikal the aerosol was sampled according to the expedition trip routes of the research vessels owned by the Limnological Institute of SB RAS - «G.Yu. Vereschagin» and «Academik V.A. Koptyug». During the period of 1993-1999 at the monitoring sites the atmospheric aerosol was sampled on filters "Whatman 41". Since the sites have been included into the EANET monitoring network, aerosol sampling is being performed by a universal method applied by the EANET and EMEP international networks (European Monitoring and Evaluation Programme). According to the EANET (2003), the samples were being taken on filters of 4 types. The filters were arranged in a successive order on a block which was tightly connected to a pump and a gas meter. The aerosol substance was collected on an external (first) teflon (PTFE) filter with a pore size about $0.8 \mu \mathrm{m}$ in diameter. Different gaseous impurities were sorbed on filters 2-4. In the aqueous extracts of the first filter, the determination of $\mathrm{Ca}^{2+}, \mathrm{Mg}^{2+}, \mathrm{Na}^{+}, \mathrm{K}^{+}, \mathrm{NH}_{4}^{+}, \mathrm{NO}_{3}^{-}, \mathrm{Cl}^{-}, \mathrm{SO}_{4}^{2-}$ ions was carried out. In the aqueous extract of Filter 2, the ions $\mathrm{SO}_{4}{ }^{2-}, \mathrm{NO}_{3}, \mathrm{Cl}^{-}, \mathrm{NH}_{4}{ }^{+}$were determined. Filter 3 was extracted with $0.05 \%$ hydrogen peroxide solution and the ions $\mathrm{SO}_{4}^{2-}, \mathrm{Cl}^{-}$were determined. In the aqueous extract of Filter 4, $\mathrm{NH}_{4}{ }^{+}$ions were determined. The corresponding gaseous impurities of $\mathrm{SO}_{2}, \mathrm{HNO}_{3}$, and $\mathrm{NH}_{3}$ were calculated and summarized from the concentrations of ions in the filtrates of filters No.2-4. To ensure the comparability with data from other regions of the world, ion analysis was carried out by modern analytical methods recommended by monitoring networks such as: atomic absorption, high-level liquid- and ion chromatography. The introduction of ions determining method by ion chromatography method made it possible to obtain the measurement results with a con- 
fidence level of $\mathrm{P}=0.95$ accurately to within $4 \%$. To compare the data, in 2000 the aerosol was collected on filters of 2 types - "Whatman 41" and PTFE. Relative determination error did not exceed $20 \%$. In an aqueous extract of an aerosol sample the composition of microelements was analyzed with the use of an inductively coupled plasma mass spectrometer produced by Agilent 7500 ce (USA). The quality of the analyses has been approved by inter-laboratory comparative experiments performed within the framework of international programs Global Atmosphere Watch (GAW, 2004) under the aegis of the World Meteorological Organization (WMO) and Acid Deposition Monitoring Network in East Asia (EANET). The results of these analyses were included in the reports of GAW (QA/SAC-Americas) and EANET (EANET, 1998-2017).

\section{The main result of studying of soluble fraction of atmospheric aerosol in the Baikal region}

\subsection{The Baikal region monitoring sites}

The main contribution to air pollution in the Baikal region is made by stationary sources, including enterprises of the fuel and energy complex, chemical, metallurgical, pulp and paper production, woodworking and construction materials production (State Reports, 1999; 2008-2017). As the Figure 1 illustrates, in the period of years $1991-1999$ total emission amount produced by stationary sources into the atmospheric air in the Irkutsk region almost halved. The least amount of impurities entered the atmosphere in 2000-2011. In 2012-2017 there was observed an increase of emissions by an average of more than $20 \%$ in comparing with the period of 2000-2011. A significant contribution to air pollution has been made by motor vehicle emissions, the amount of which increases annually by more than 10 thousand units (BSM, 2016). An additional contribution to air pollution comes from forest and peat fires which is difficult to quantify.

The most detailed studies of the chemical composition of the soluble fraction of the aerosol at the mon-

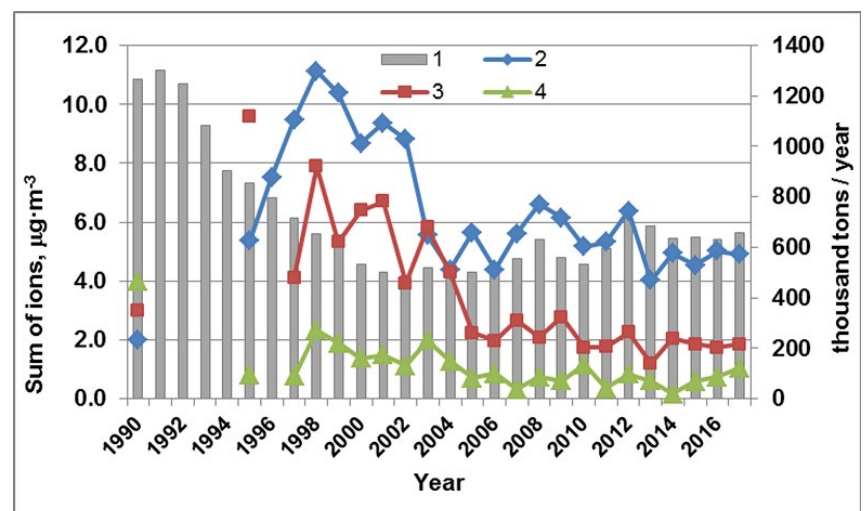

Fig. 1. Emissions of pollutants into the atmosphere (1) by stationary sources (total for the region, thousand tons/year) and the dynamics of interannual total concentrations of ions in the atmospheric aerosol at monitoring sites: Irkutsk (2), Listvyanka (3), Mondy (4), $\mu \mathrm{g} \cdot \mathrm{m}^{-3}$ itoring sites began to be carried out since 1995. Figure 1 shows the average annual concentrations of the total content of ions in the composition of the soluble aerosol fraction at the atmospheric monitoring stations over the 16-year observation period. Long-term annual average of ion concentrations varied within the wide range and amounted to $4.0-11.1 \mu \mathrm{g} \cdot \mathrm{m}^{-3}$ for Irkutsk, Listvyan$\mathrm{ka}-1.2-9.6 \mu \mathrm{g} \cdot \mathrm{m}^{-3}$, and Mondy sites - 2.2-2.3 $\mu \mathrm{g} \cdot \mathrm{m}^{-3}$. Changes in ion concentration of the aerosol are in fair agreement with the dynamics of atmospheric emissions from stationary sources in Irkutsk region, especially at sites Irkutsk and Listvyanka. There is a decrease in the concentration of ions of the aerosol observed at all stations from 1998 till 2006-2017. The average ion content in the aerosol of Irkutsk decreased by 2.1 times, Listvyanka - 4.0 times, at Mondy site - 3.5 times.

In the seasonal aspect the highest ion concentrations in the aerosol at Irkutsk and Listvyanka stations were observed during the cold season. At Mondy site the annual course of ion concentrations is less pronounced. At this site a distribution with its maximum during the warm season was predominant. That indicates a predominant soil-erosion source of impurities in the atmosphere of this region. In some years (2004, 2007, 2009, 2014, 2017) some elevated concentrations were observed either in December or in January. In 2016 the annual course of the sum of ions at Mondy site was similar to those at Irkutsk and Listvyanka sites with the maximum during the entire cold period. This may indicate an increase of the influence of global transportation of pollutants in the atmosphere of the background area due to increased production volumes (Overview, 2017).

The dominant in the composition of the aerosol of the Baikal region were ions of continental origin both natural and anthropogenic character, $\mathrm{NH}_{4}^{+}, \mathrm{Ca}_{2}^{+}$, NO3, SO42. Earlier the authors noted that in 20052015 compared to 1995-1999 a qualitative change occurred in the composition of the predominant ions at Listvyanka and Mondy sites against the changes in the quantitative characteristics of the aerosol. The role of alkaline-earth components decreased in Listvyanka aerosol, the main ions became $\mathrm{NH}_{4}{ }^{+}, \mathrm{NO}^{-}$and $\mathrm{SO}_{4}{ }^{2-}$. At Mondy site the influence of the alkaline components $\mathrm{K}^{+}$and $\mathrm{Na}^{+}$, as well as the ions $\mathrm{Cl}^{-}, \mathrm{SO}_{4}{ }^{2-}, \mathrm{NO}_{3}^{-}$, oppositely increased (Golobokova et al., 2018).

The most relevant is the state of atmospheric aerosol in the present period. The dynamics of ions in the aerosol at the monitoring sites in 2014-2017 was being considered. Similar seasonal dynamics of ion concentrations in the aerosol composition is observed at Irkutsk and Listvyanka sites with a minimum of concentrations in the warm period of the year and an increase of the concentrations in the cold one. Despite the decrease of ion concentrations in the warm period of the year, the concentrations increase at Listvyanka site in July. At Mondy site there are two maximum of concentrations of ions - in March and August with a higher content in March. It is characteristic that the increase in ion concentrations in Listvyanka and Mondy in the summer period is observed during the season of increased precipitation at the sites. The difference in con- 
centrations in the aerosol between the sites of Irkutsk and Mondy averages 7.6 times, between Listvyanka and Irkutsk - 2.6. The total content of ions in 2014-2017 at the site of Irkutsk varied within $4.5-5.0 \mu \mathrm{g} \cdot \mathrm{m}^{-3}$, at Listvyanka site $-1.3-2.0 \mu \mathrm{g} \cdot \mathrm{m}^{-3}$, and at Mondy site there was noted an increase in the total concentration of ions by 2017 from $0.17 \mu \mathrm{g} \cdot \mathrm{m}^{-3}$ to $1.04 \mu \mathrm{g} \cdot \mathrm{m}^{-3}$.

As the Figure 2 shows, in 2014-2015 at Mondy site sulfates and chlorides prevailed among anions, ammonium and calcium prevailed among cations, in the summer period the role of sodium ions increased. In 2016 the proportion of sulfates increased and the role of chlorides decreased, the proportion of ammonium increased noticeably, in 2017 there were no noticeable changes among anions and the proportion of sodium among cations increased especially in spring. At the site of Irkutsk there were no significant changes during 2014-2016. In 2017 there is a decrease in the proportion of ammonium was noticed and an increase of sodium and potassium was observed. Similar changes in 2017 occurred at Listvyanka site.

Such multidirectional trends in the composition of the aerosol that emerge at the monitoring sites in 2014-2017 can be explained by the different synoptic conditions of each particular year, although in general the overall picture remains: the distribution of the ionic composition with the dominance of sulfates, ammonium and calcium.

\subsection{Aerosol of the near-water layer of the atmo- sphere of Lake Baikal water area}

The aerosol over Lake Baikal water area was collected in the spring (May / June) and summer (July / August) periods of 2010-2017. Early studies (20052008) showed that in the central part of Central and Northern Baikal the submicron aerosol fraction dominates with a total ion concentration of $0.1-0.7 \mu \mathrm{g} \cdot \mathrm{m}^{3}$ and $\mathrm{NH}_{4}{ }^{+}$and $\mathrm{SO}_{4}{ }^{2-}$ ions predominant in its composition (Golobokova et al., 2011). These parameters allow to refer the Baikal aerosol to the background one. The change of its chemical composition can be significantly influenced by various factors both of natural and anthropogenic characters. One of such factors is emerging adverse meteorological and environmental phenomena.

During the sampling period the most adverse me- teorological phenomena were observed in June 2010, when the air on the shores of Lake Baikal warmed up to $25-30^{\circ} \mathrm{C}$, and especially in 2012 , when the territory of Irkutsk region was anomalously dry, the weather was abnormally hot in July (average monthly air temperature was $2-3^{\circ}$ above normal), intense dry hot winds blew and such a weather led to the air drought and then to the soil drought in June (State Reports, 2013). An important role in air pollution above Lake Baikal is assigned to forest and peat fires which deliver to the atmosphere some suspended particles, ammonium and potassium compounds, chlorides, organic components, and many others (Recommendation..., 2015). The most intense forest fires in the region including the fires in the immediate vicinity of Lake Baikal happened in 2015-2016 when the region was experiencing the 5th class emergency of fire hazard of forests. (State Reports, 2008-2017). To detect common similarities and differences in the ionic composition of the aerosol in the period of 2010-2017 the data was averaged separately for each of the lake basins. Statistical characteristics (mean - and mean-square deviations - MSD) were determined from the average results calculated for each year. The results of the study showed that despite the influence of forest fires the tendency earlier revealed persisted: the total content of the ions in the aerosol composition is the highest in the atmosphere of Southern Baikal (1.56 \pm $\left.1.36 \mu \mathrm{g} \cdot \mathrm{m}^{-3}\right)$, and the lowest one is in the atmosphere of Northern Baikal $\left(1.13 \pm 1.00 \mu \mathrm{g} \cdot \mathrm{m}^{-3}\right)$ (Table 1). Differences in the ratio of the ions and their concentrations between the lake basins are connected primarily with differences in the environmental conditions of the coasts (Khodhzer et al., 1994; Van Malderen et al., 1996; Golobokova et al., 2011). Besides, the BPPM, which was closed in 2013, operated for a long time in Southern basin.

Comparison of the sum of the ion concentrations in the aerosol in 2010-2017 with similar data of 2005-2008 showed an increase of the concentrations of 1.5 times in the composition of the aerosol above Southern Baikal, 1.7 times higher above Central Baikal and 1.9 times higher above Northern Baikal. The highest increase in the concentrations of 3-7 times was observed for ионов $\mathrm{Na}^{+}, \mathrm{K}^{+}, \mathrm{NH}_{4}^{+}, \mathrm{Cl}^{-}, \mathrm{NO}_{3}^{-}$ions in the aerosol of Northern and Central Baikal where intense forest fires happened in 2015-2016. The mean concen-

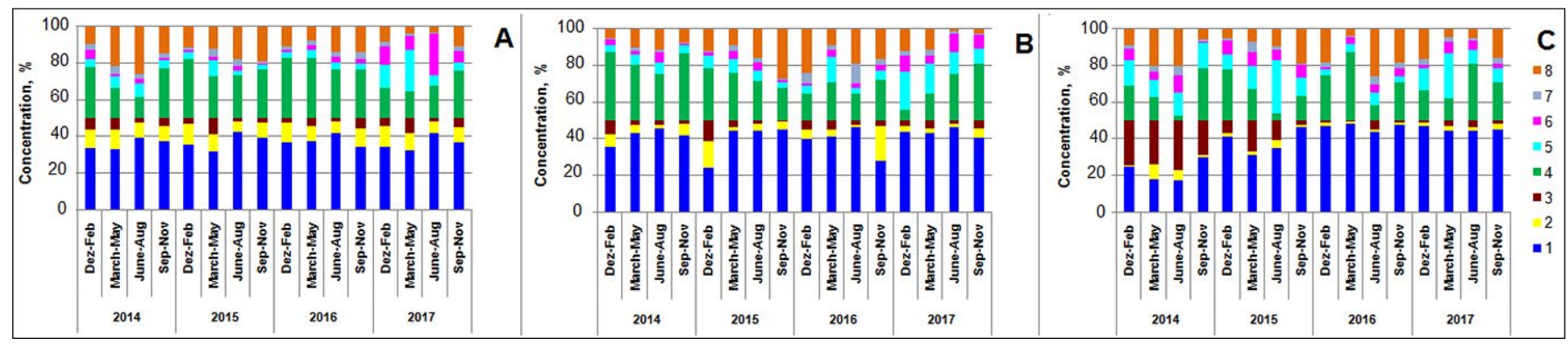

A - Irkutsk, B - Listvyanka, C - Mondy

1- $\mathrm{SO}_{4}^{2-}, 2-\mathrm{NO}_{3}^{-}, 3-\mathrm{Cl}^{-}, 4-\mathrm{NH}_{4}^{+}, 5-\mathrm{Na}^{+}, 6-\mathrm{K}^{+}, 7-\mathrm{Mg}^{2+}, 8-\mathrm{Ca}^{2+}$

Fig. 2. Seasonal variability of ion concentrations in atmospheric aerosol composition at monitoring sites of Lake Baikal region in 2014-2017, \% 
Table 1. Average concentrations of ions $(\overline{\mathrm{x}})$, meansquare deviations of concentrations (MSD), total of ions $\left(\Sigma_{\text {ion }}\right)$ in the aerosol over Lake Baikal water area in 2010-2017, $\mu \mathrm{g} \cdot \mathrm{m}^{-3}$

\begin{tabular}{|l|c|c|c|c|c|c|}
\hline \multirow{2}{*}{ Component } & \multicolumn{2}{|c|}{ Southern Baikal } & \multicolumn{2}{c|}{ Central Baikal } & \multicolumn{2}{c|}{ Northern Baikal } \\
\cline { 2 - 7 } & $\overline{\mathbf{x}}$ & \pm MSD & $\overline{\mathbf{x}}$ & \pm MSD & $\overline{\mathbf{x}}$ & \pm MSD \\
\hline $\mathbf{N a}^{+}$ & 0.11 & 0.08 & 0.12 & 0.12 & 0.16 & 0.30 \\
$\mathbf{N H}_{4}{ }^{+}$ & 0.26 & 0.44 & 0.15 & 0.21 & 0.09 & 0.15 \\
$\mathbf{K}^{+}$ & 0.20 & 0.41 & 0.15 & 0.26 & 0.15 & 0.33 \\
$\mathbf{M g}^{2+}$ & 0.01 & 0.01 & 0.01 & 0.01 & 0.01 & 0.01 \\
$\mathbf{C a}^{2+}$ & 0.12 & 0.09 & 0.07 & 0.06 & 0.07 & 0.07 \\
$\mathbf{C l}^{-}$ & 0.20 & 0.33 & 0.14 & 0.20 & 0.12 & 0.23 \\
$\mathbf{N O}_{3}^{-}$ & 0.08 & 0.05 & 0.12 & 0.16 & 0.13 & 0.18 \\
$\mathbf{S O}_{4}{ }^{2-}$ & 0.58 & 0.49 & 0.41 & 0.35 & 0.40 & 0.49 \\
$\Sigma_{\text {ion }}$ & 1.56 & 1.36 & 1.17 & 0.78 & 1.13 & 1.00 \\
\hline
\end{tabular}

trations of $\mathrm{Ca}_{2}{ }^{+}$and $\mathrm{SO}_{4}^{2-}$ did not change. The growth of ion concentrations in the atmospheric aerosol was influenced not only by forest fires, but also by the meteorological conditions of 2010 and 2012. Figure 3 clearly demonstrates the results of the ion content in the aerosol during different observation periods, including seasons with adverse meteorological conditions. High concentrations of ions were observed in spring 2012 during the period of abnormally dry weather with its maximum concentration in Southern Baikal (2.3-5.2 $\mu \mathrm{g} \cdot \mathrm{m}^{-3}$ ) and during forest fires in spring 2016 when the mean content of ions over the entire Baikal water area was 2.2-3.2 $\mu \mathrm{g} \cdot \mathrm{m}^{-3}$. The minimum total concentrations of ions were determined in the spring periods of 2014 and 2015 when their mean concentrations varied from 0.33 to $0.78 \mu \mathrm{g} \cdot \mathrm{m}^{-3}$.

Among the microelements in the composition of the soluble fraction of the aerosol, elements of mainly soil-erosion origin were predominant: $\mathrm{Al}, \mathrm{Fe}, \mathrm{Zn}, \mathrm{Sr}$, Mo, and Ba. Above the water area of the southern part of Lake Baikal the concentrations of all analysis elements were higher. The concentrations of elements in the aerosol, as well as the concentration of ions, are influenced by the combustion products of forest fires. Table 2 shows a comparison of the concentrations of some microelements in the aerosol sampled in August 2015 compared with the mean concentrations in the aerosol sampled in 2008-2010, 2015 and 2017. The increase in concentration occurred from 1.4 to 6 times. The greatest increase in the concentrations of elements was observed in the aerosol of Central and Northern Baikal.

The soil and the earth's crust are the main sources of aerosol of the continental regions, and as a result, the ratio of elements in the aerosol from different regions of the world is very close and corresponds to that one for the earth's crust's (Rahn, 1976; Lowenthal et al., 1985; Swietlicki, 1989). In this regard, against the background of absolute concentrations of elements, it is rather difficult to estimate the contribution of the an-

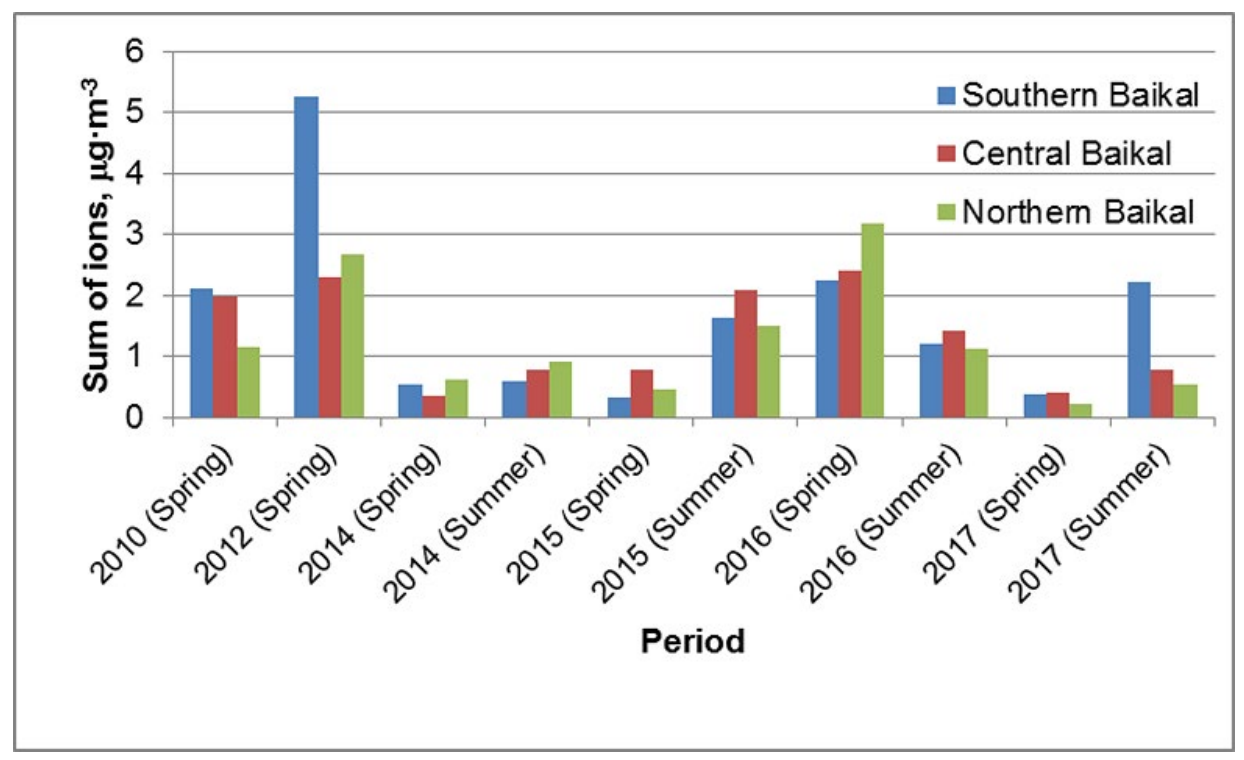

Fig. 3. Dynamics of the interannual total concentrations of ions in the atmospheric aerosol in the near-water layer over Lake Baikal water area, 2010-2017, $\mu \mathrm{g} \cdot \mathrm{m}^{-3}$ 
Table 2. Comparison of mean concentrations of elements in the composition of the soluble fraction of the aerosol of the near-water layer over Lake Baikal water area in diffrent periods, $\mathrm{ng} / \mathrm{m}^{3}$

\begin{tabular}{|c|c|c|c|c|c|c|}
\hline \multirow{2}{*}{ Element } & $\begin{array}{c}\text { Southern } \\
\text { Baikal }\end{array}$ & $\begin{array}{c}\text { Central Bai- } \\
\text { kal }\end{array}$ & $\begin{array}{c}\text { Northern } \\
\text { Baikal }\end{array}$ & $\begin{array}{c}\text { Southern } \\
\text { Baikal }\end{array}$ & $\begin{array}{c}\text { Central Bai- } \\
\text { kal }\end{array}$ & $\begin{array}{c}\text { Northern } \\
\text { Baikal }\end{array}$ \\
\cline { 2 - 7 } & \multicolumn{2}{|c|}{ mean value in 2008-2010; 2015; 2017 } & \multicolumn{3}{|c|}{ August 2015 } \\
\hline Al & 87.8 & 77.5 & 36.8 & 448.2 & 408.5 & 176.2 \\
V & 0.23 & 0.11 & 0.07 & 0.32 & 0.23 & 0.15 \\
Zn & 110.2 & 123.0 & 59.9 & 443.3 & 662.9 & 318.4 \\
As & 0.17 & 0.08 & 0.05 & 0.23 & 0.25 & 0.18 \\
Sr & 4.1 & 4.2 & 2.5 & 20.2 & 23.7 & 14.5 \\
Ba & 178.7 & 204.1 & 121.1 & 1045.9 & 1216.0 & 713.8 \\
W & 2.8 & 2.3 & 1.5 & 10.5 & 10.9 & 6.8 \\
Pb & 0.50 & 0.48 & 0.26 & 1.47 & 1.59 & 0.87 \\
\hline
\end{tabular}

thropogenic component. We calculated the enrichment factors of the elements relative to Al (Fig. 4). According to the factors it was revealed that the greatest enrichment of aerosol particles comes by the elements $\mathrm{Zn}$, Se, Mo and As. Comparison of mean factors of enrichment of chemical elements in Baikal aerosol with factors of enrichment of three global types of aerosols - «urban», «background continental», «sea» (Rahn, 1976) - indicates that factors of enrichment of most of the elements of Baikal aerosol are closer in size to « background continental» type of aerosol.

\subsection{Vertical fluxes $\mathbf{S}$ and $\mathbf{N}$ with dry deposition}

One of the environmental criteria for the Baikal region is the assessment of sulfur and nitrogen inputs on the underlying surface. The most likely adverse effect of the transfer of sulfur and nitrogen to Lake Baikal was the acidification of atmospheric precipitations, which led to a shift in the balance of the main ions in the waters of Southern Baikal inflows (Sorokovikova et al., 2004; Obolkin et al., 2016). The flows of sulfur and nitrogen coming from the atmosphere with an aerosol were recalculated for nitrogen from nitrates and ammonium ions, and for sulfur - from sulfates. The input of nitrogen with gases was calculated from the sum of gaseous impurities $\mathrm{HNO}_{3}$ and $\mathrm{NH}_{3}$, sulfur from $\mathrm{SO}_{2}$. The following formula was used for calculations: $\mathrm{D}=\mathrm{CV} \Delta \mathrm{t}$, where $\mathrm{D}$ is the input of substances, $\mathrm{C}$ is the mean concentration over the period $\Delta \mathrm{t}, \mathrm{V}$ is the speed of dry depositions. To compare the data dry deposition rates were used taking into account the type of surface and certain climatic conditions previously used (Paramonov et al., 1999; Golobokova et al., 2007). Emission of impurities from the atmosphere to the underlying surface at the monitoring sites was considered for the period of 20002017. Sulfur and gas flows were higher at all the sites. This distribution of substances was also noted earlier

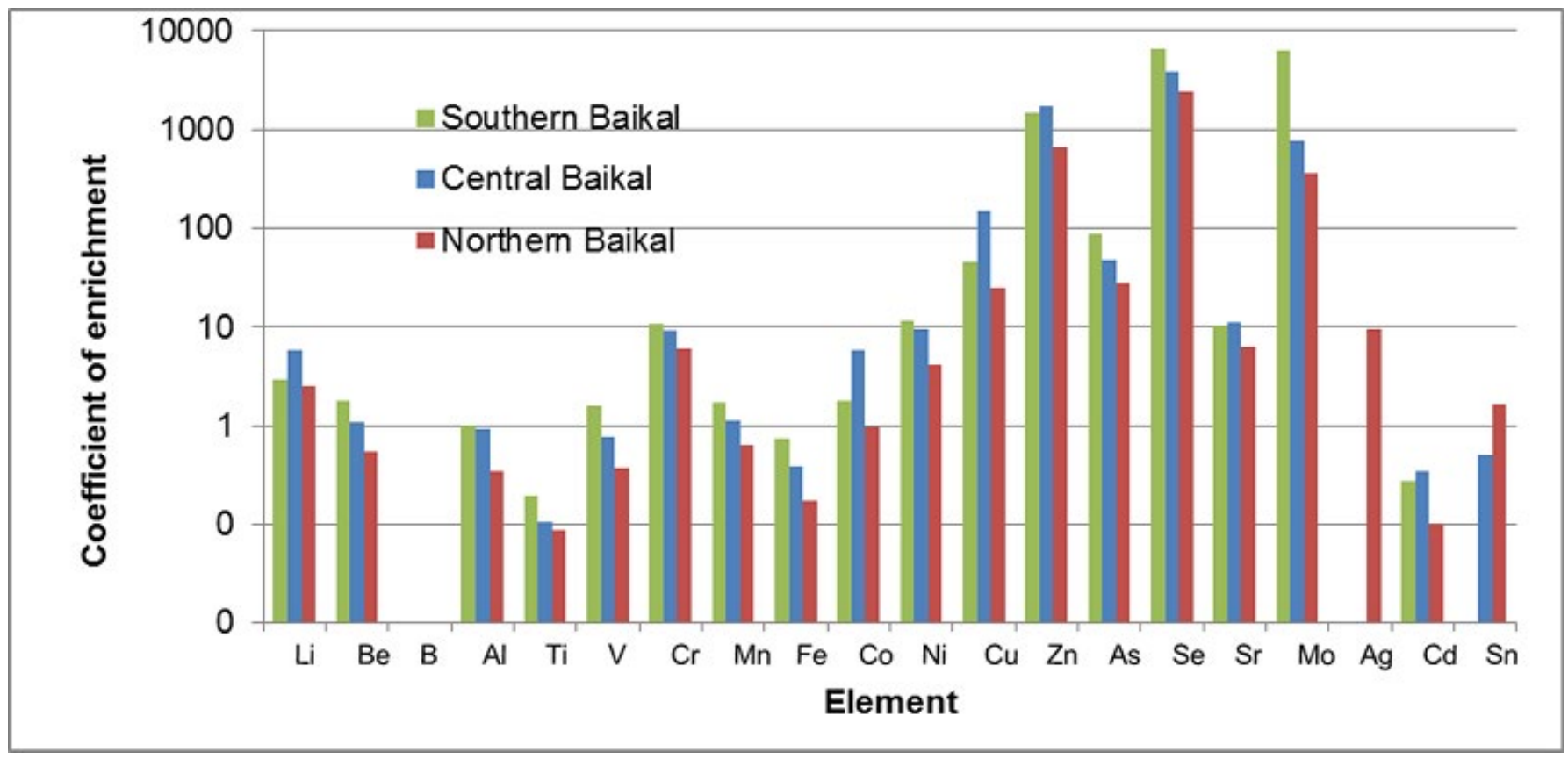

Fig. 4. Factors of enrichment of Baikal aerosol 
Table 3. Sulfur and nitrogen flows at monitoring sites, ton $\mathrm{km}^{-2}$ year-1

\begin{tabular}{|c|c|c|c|c|c|c|}
\hline \multirow{2}{*}{ Year } & \multicolumn{2}{|c|}{ Irkutsk } & \multicolumn{2}{c|}{ Listvyanka } & \multicolumn{2}{c|}{ Mondy } \\
\cline { 2 - 7 } & $\mathbf{N}$ & $\mathbf{S}$ & $\mathbf{N}$ & $\mathbf{S}$ & $\mathbf{N}$ & $\mathbf{S}$ \\
\hline $\mathbf{2 0 0 0}$ & 132 & 511 & 147 & 223 & 30 & 26 \\
$\mathbf{2 0 0 1}$ & 134 & 522 & 67 & 191 & 27 & 45 \\
$\mathbf{2 0 0 2}$ & 114 & 163 & 63 & 256 & 39 & 38 \\
$\mathbf{2 0 0 3}$ & 128 & 232 & 138 & 258 & 38 & 63 \\
$\mathbf{2 0 0 4}$ & 68 & 249 & 77 & 147 & 17 & 113 \\
$\mathbf{2 0 0 5}$ & 84 & 1004 & 37 & 918 & 41 & 279 \\
$\mathbf{2 0 0 6}$ & 128 & 506 & 163 & 736 & 65 & 78 \\
$\mathbf{2 0 0 7}$ & 182 & 642 & 96 & 234 & 26 & 42 \\
$\mathbf{2 0 0 8}$ & 140 & 526 & 69 & 264 & 26 & 64 \\
$\mathbf{2 0 0 9}$ & 121 & 563 & 87 & 528 & 5 & 15 \\
$\mathbf{2 0 1 0}$ & 95 & 892 & 72 & 507 & 10 & 79 \\
$\mathbf{2 0 1 1}$ & 72 & 851 & 40 & 334 & 10 & 48 \\
$\mathbf{2 0 1 2}$ & 71 & 926 & 32 & 680 & 16 & 127 \\
$\mathbf{2 0 1 3}$ & 65 & 599 & 42 & 356 & 14 & 40 \\
$\mathbf{2 0 1 4}$ & 72 & 332 & 69 & 256 & 7 & 40 \\
$\mathbf{2 0 1 5}$ & 134 & 621 & 100 & 419 & 12 & 59 \\
$\mathbf{2 0 1 6}$ & 153 & 761 & 147 & 500 & 59 & 72 \\
$\mathbf{2 0 1 7}$ & 134 & 830 & 115 & 499 & 42 & 86 \\
\hline
\end{tabular}

(Golobokova et al., 2007; Obolkin et al., 2016). The nitrogen flows with aerosol at Irkutsk site were higher in 2001, 2012 and 2015-2017, at Listvyanka site the flow was higher in 2001-2002 and 2012, at Mondy site the flows with gases were prevalent during all year round. The deposition of sulfur with gases was maximum for all the sites in 2005-2006 and 2009-2013 at average, the deposition of nitrogen in Irkutsk and Listvyanka was maximum in 2005-2011, at the site of Mondy in 2004-2008. The change in the sulfur and nitrogen flows at the sites has a similar interannual variation, despite the fact that at Mondy site the emission of nitrogen is 4 times less upon average and the emission of sulfur is 8 times less, at Listvyanka site the level of nitrogen is 1.3 times less, sulfur is 1.5 times less than in Irkutsk (Table 3). Over the last years (2015-2017) in Irkutsk, the flows of sulfur and nitrogen with aerosol decreased, but the flows with gases increased. In Listvyanka, on the contrary, the input of nitrogen with aerosol increased, the input with gases decreased, the flow of sulfur in 2016-2017 almost remained unchanged. At Mondy site the sulfur flows with aerosol decreased and increased with gases similarly as in Irkutsk. As in Listvyanka the flow of nitrogen with aerosol increased and decreased with gases.

An intake of sulfur and nitrogen all round Lake Baikal was analyzed. The intake of these substances to Baikal varies as well as at monitoring sites year by year and depends on the synoptic situation, meteorological conditions and forest fires whose frequency has increased in recent years. The highest flows of sulfur and nitrogen were determined over the water area of Southern Baikal, the flows over Central Baikal were 1.4-1.5 times lower, over Northern Baikal - 1.8 times lower. Over the water area of South Baikal nitrogen and sulfur flows increased in 2010-2017 in comparison with the period of 2005-2008 by 2.2 and 1.1 times correspondingly (Table 4). Above Central and Northern Baikal there is an increase in nitrogen-only flows by 1.7 and 1.5 times and a decrease in sulfur flows by 1.1 and 1.5 times.

In general, the increase in nitrogen flows over Lake Baikal water area was observed in 2007, 2012, 2015 and 2016, in sulfur flows - in 2007, 2010 and 2016. The minimum intake of these substances was noted in 2014.

\section{Conclusions}

Long-term (1995-2017) studies of the chemical composition of atmospheric aerosol in Baikal region were carried out at the monitoring sites of Irkutsk, Listvyanka and Mondy. The quantitative estimates of spatial heterogeneity, interannual variability and seasonal dynamics of its composition are established. A gradual decrease in the sum of the concentrations of the main ions in the aerosol was noted: in Irkutsk by 2.1 times, in Listvyanka by 4.0 times, at the background site of Mondy by 3.5 times by $2006-2017$ in comparison with the period of 1998 .

In the present period (2014-2017), the difference in total concentrations in the aerosol between Irkutsk 
Table 4. Monthly average nitrogen and sulfur flows over Lake Baikal, ton $\mathrm{km}^{-2}$

\begin{tabular}{|c|c|c|c|c|c|c|}
\hline \multirow{2}{*}{ Period } & \multicolumn{2}{|c|}{ Southern Baikal } & \multicolumn{2}{c|}{ Central Baikal } & \multicolumn{2}{c|}{ Northern Baikal } \\
\cline { 2 - 7 } & $\mathbf{N}$ & $\mathbf{S}$ & $\mathbf{N}$ & $\mathbf{S}$ & $\mathbf{N}$ & $\mathbf{S}$ \\
\hline $\mathbf{2 0 0 5 - 2 0 0 8}$ & 66.4 & 181.2 & 64.0 & 144.0 & 53.3 & 156.7 \\
$\mathbf{2 0 1 0 - 2 0 1 7}$ & 149.1 & 196.0 & 108.3 & 126.8 & 81.2 & 106.4 \\
\hline
\end{tabular}

and Mondy sites averages 7.6 times, between Listvyanka and Irkutsk -2.6 times. The total content of ions in 2014-2017 at Irkutsk site varied within 4.5-5.0 $\mu \mathrm{g} \cdot \mathrm{m}^{-3}$, at Listvyanka site $-1.3-2.0 \mu \mathrm{g} \cdot \mathrm{m}^{-3}$, and at the Mondy site an increase in the total concentration of ions was noted - from $0.17 \mu \mathrm{g} \cdot \mathrm{m}^{-3}$ to $1.04 \mu \mathrm{g} \cdot \mathrm{m}^{-3}$ by 2017 . Dissimilarity of the chemical composition is determined by the diversity of physiographic conditions of the region and by the degree of anthropogenic factors influence. The dominant in the composition of the aerosol of the Baikal region were ions of continental, both of natural and anthropogenic origin, $\mathrm{NH}_{4}{ }^{+}, \mathrm{Ca}^{2}{ }_{+}, \mathrm{NO}^{3}, \mathrm{SO}_{2}{ }_{2}$.

Against the background of changes in the quantitative characteristics of the aerosol, a qualitative change in the composition of the predominant characteristics took place at the sites. In the aerosol of Mondy site, the proportion of sulfates increased in 2016 and the role of chlorides decreased, the proportion of ammonium increased noticeably, in 2017 there were no noticeable changes among anions, and the proportion of sodium among cations increased especially in spring. At Irkutsk site during 2014-2016 special changes were not observed. In 2017 in the aerosol of Irkutsk and Listvyanka, there was a decrease in the proportion of ammonium and an increase in sodium and potassium.

In the near-water layer of Lake Baikal the average perennial (2010-2017) total ion concentrations were the highest in the aerosol of Southern Baikal $\left(1.56 \pm 1.36 \mu \mathrm{g} \cdot \mathrm{m}^{-3}\right)$, the lowest - in the atmosphere of Northern Baikal $\left(1.13 \pm 1.00 \mu \mathrm{g} \cdot \mathrm{m}^{-3}\right)$. The inter-annual and spatial heterogeneity of the chemical composition of aerosol of Lake Baikal was greatly influenced by adverse meteorological conditions of 2010 and 2012 and forest fires of 2015-2016.

High concentrations of ions were detected during the periods of abnormally dry weather (2.3$\left.5.2 \mu \mathrm{g} \cdot \mathrm{m}^{-3}\right)$ and forest fires $\left(2.2-3.2 \mu \mathrm{g} \cdot \mathrm{m}^{-3}\right)$. The minimum total concentrations of ions were observed in the absence of external influences $\left(0.33-0.78 \mu \mathrm{g} \cdot \mathrm{m}^{-3}\right)$. The elemental composition of the aerosol is dominated by components of soil-erosion origin ( $\mathrm{Al}, \mathrm{Fe}, \mathrm{Zn}, \mathrm{Cr}, \mathrm{Ba}$ ), the concentration of which increases during fire danger periods by an average of 1.4-6 times.

The flows of sulfur and nitrogen, the main acidifying components, differ in different years of observations both at the monitoring sites and over the surface of Lake Baikal. The determining factors, which influence on the chemical composition of the aerosol and the flows of substances, are the orographic heterogeneities of the underlying surface, production emissions, meteorological phenomena and forest fires.

\section{Acknowledgments}

This study was supported by State Project 003452016-0008 (expeditionary work and data interpretation) and RFBR project 17-29-05044 (chemical data analysis). The investigations were carried out using Shared Research Facilities for Physical and Chemical Ultramicroanalysis LIN SB RAS. The authors are grateful to colleagues at the Laboratory of Hydrochemistry and Atmospheric Chemistry of Limnological Institute of SB RAS O.G. Netsvetaeva, I.I. Marinayte, M.V. Sakirko for assisting in the sampling of atmospheric aerosol over Lake Baikal water area.

\section{References}

Anokhin Yu. A., Kokorin A.O., Prokhorova T.A. et al. 1991. Aerosol pollution of atmosphere above Lake Baikal and effect of industrial sources (1991). In: Israel Yu.A., Anokhin Yu.A. (Eds.), Monitoring sostoyaniya ozera Baikal [Monitoring of Lake Baikal state] Leningrad: Hydrometeoizdat, pp. 44-50. (in Russian)

Balin Yu.S., Klemasheva M.G., Kokhanenko G.P. et al. 2016. Lidar study of the vertical structure of aerosol fields in the atmosphere over Lake Baikal during forest fires. Atmospheric and oceanic optics 29: 689-693. (in Russian)

Belan B.D., Zuev V.E., Kovalevsky V.K. et al. 1996. Comprehensive assessment of the state of the air basin over the Baikal and Lake Baikal. Russian Meteorology and Hydrology 10: 39-50. (in Russian)

BSM (Brief Statistical Manual). 2016. Irkutsk Regional Brief Statistical Manual. [http://irkutskstat.gks.ru/wps/ $\mathrm{wcm} /$ connect/rosstat_ts/irkutskstat/ru/publications/official_publications/electronic_versions. Last Access: 07 October 2017]

EANET (Acid Deposition Monitoring Network in East Asia). 1998-2017. Report of the Inter-Laboratory Comparison Project. [http://www.eanet.asia/product/index.html. Last Access: 29 October 2018]

EANET (Acid Deposition Monitoring Network in East Asia). 2000. Report on the Acid Deposition Monitoring of EANET during the Preparatory Phase. [http://www.eanet.asia/ site/index.html. Last Access: 29 October 2018]

GAW (Global Atmosphere Watch). 2004. Manual for the gaw precipitation chemistry programme. WMO-GAW Report No. 160. In: Allan M.A. (Ed.), Precipitation chemistry [manual. http://qasac-americas.org. Last Access: 01 November 2018]

Golobokova L.P., Kobeleva N.A., Makukhin V.L. et al. 2002. Some Results of Experimental Observations and Mathematical Simulation of Distribution of Acidifying Atmospheric Admixtures in the Region of Southern Baikal. Chemistry for Sustainable Development 10: 575-583.

Golobokova L.P. 2004. Development and application of techniques for studies of chemical composition of gaseous impurities and atmospheric aerosol (exemplified by Baikal 
Natural Territory). Cand. Sc. Dissertation, Institute for Water and Environmental Problems SB RAS, Barnaul, Russia. (in Russian)

Golobokova L.P., Latysheva I.V., Mordvinov V.I. et al. 2005. Peculiarities in the chemical composition of atmospheric aerosol against the background of extreme weather conditions in Southern Siberia. Atmospheric and oceanic optics 18: 616-620

Golobokova L.P., Latysheva I.V., Ivanova A.S. et al. 2006. Mesoclimatic and aerosynoptic conditions of ionic composition formation of atmospheric aerosol in high-mountain regions of Eastern Sayans. Geography and Natural Resources 2: 83-88

Golobokova L.P., Khodzher T.A., Khodzher T.V. 2007. Current estimate of dry surface deposition of chemical substances in different regions of Asian territory of Russia. Atmospheric and oceanic optics 20: 470-473

Golobokova L.P., Filippova U.G., Marinaite I.I. et al. 2011. Chemical composition of atmospheric aerosol above the Lake Baikal area. Atmospheric and oceanic optics 24: 236-241. (in Russian)

Golobokova L. P., Khodzher T.V., Obolkin V.A. et al. 2018. Long-term investigations of atmospheric aerosol and gaseous impurities in Southern Pribaikalye, East Siberia (Russia). International Journal of Environmental Sciences and Natural Resources 10: 555786. DOI: 10.19080/ IJESNR.2018.10.555786

Khodzher T.V. 1983. Chemical composition of atmospheric precipitation. Ecology of Southern Baikal. Irkutsk, pp. 44-50. (in Russian)

Khodzher T.V., Potemkin V.L., Obolkin V.A. 1994. Chemical composition of aerosol and trace gases in the atmosphere over Lake Baykal. Atmospheric and oceanic optics 7: 566569.

Khodzher T.V., Golobokova L.P., Obolkin et al. 1997a. Diurnal and seasonal variability of the atmospheric aerosol ion composition in the south of East Siberia. Atmospheric and oceanic optics 10: 403-406

Khodzher T.V., Obolkin V.F., Potemkin, V.L. et al. 1997b. Seasonal variability of the elemental composition of atmospheric aerosols above Lake Baikal. Chemistry for Sustainable Development 5: 547-561. (in Russian)

Khodzher T.V. 2005. Study of composition of atmospheric precipitation and its effect on ecosystem of the Baikal Natural Territory. Dr. Sc. Dissertation, V.B. Sochava Institute of Geography SB RAS, Irkutsk, Russia. (in Russian)

Koutsenogii P.K., Bufetov N.S., Drosdova V.I. et al. 1993. Ion composition of atmospheric aerosol near Lake Baikal. Atmospheric Environment 27A: 1629-1633.

Lowenthal D., Rahn K. 1985. Regional sources of pollution aerosol at Barrow, Alaska during winter 1979-80, as deduced from elemental tracers. Atmospheric Environment 19: 2011-2024.

Mattias-Maser S., Obolkin V., Khodzher T. et al. 2000. Seasonal variation of primary biological aerosol particles in the remote continental region of Lake Baikal, Siberia. Atmospheric Environment 34: 3805-3811. DOI: 10.1016/S13522310(00)00139-4

Obolkin V.A., Khodzher T.V. 1990. Annual input of sulfate and mineral nitrogen from atmosphere in the area of
Lake Baikal. Russian Meteorology and Hydrology 7: 71-76. (in Russian)

Obolkin V.F., Potemkin V.L., Khodzher T.V. 1994. Elemental composition and main sources of atmospheric aerosol of Southern Baikal. Geography and Natural Resource 3: 75-81.

Obolkin V., Khodzher T., Sorokovikova L. et al. 2016. Effect of long-range transport of sulphur and nitrogen oxides from large coal power plants on acidification of river waters in the Baikal region, East Siberia. International Journal of Environmental Studies 73: 452-461. DOI: 10.1080/00207233.2016.1165481

Obolkin V.A., Potemkin V.L., Makukhin V.L. et al. 2017. Far transfer of trails, ejected by regional electric power stations to the South Baikal water area. Atmospheric and Oceanic Optic 30: 360-365. DOI: 10.1134/S1024856017040078

Overview of the state and pollution of the environment in the Russian Federation for 2016. 2017. Federal Service for Hydrometeorology and Environmental Monitoring (Roshydromet), Moscow, SBN 978-5-904131-48-7.

Paramonov S., Ryaboshapko A., Gromov S. et al. 1999. Sulfur and nitrogen compounds in air and precipitation over the former Soviet Union in 1980-1995. Report CM-95. International Meteorolodgical Institute, Stockgolm.

Rahn K.A. 1976. The chemical composition of the atmospheric aerosol. Technical Report, University of Rhode, Island.

Recommendation on peat fire extinguishing on dried bogs. Experience of volunteer forest firemen. 2015. Moscow: Cityprint. (in Russian)

Sorokovikova L.M., Netsvetaeva O.G., Tomberg I.V. et al. 2004. Effect of atmospheric precipitation on the chemical composition of river waters in the South Baikal region. Atmospheric and oceanic optics 17: 373-377.

State Reports «On State and Protection of the Irkutsk Region Environment for 1999». 2000. State Environmental Protection Committee of the Irkutsk Region. Irkutsk, 319 p. (in Russian)

State Reports «On State and Protection of the Irkutsk Region Environment». 2008-2017. [http://irkobl.ru/sites/ecology/picture, Last Access: 29 October 2018]. (in Russian)

State Reports «On State and Protection of the Irkutsk Region Environment». 2013. [http://irkobl.ru/sites/ecology/ picture. Last Access: 28 October 2018]. (in Russian)

Swietlicki E. 1989. European source region identification of long range transported ambient aerosol based on PIXE analysis and related techniques. Lund, Sweden.

Van Maldren H., van Griken R., Khodzher T.V. et al. 1994. Analysis of individual aerosol particles in Siberian region. Provisional results. Atmospheric and oceanic optics 7: 622-626.

Van Malderen H., Van Grieken R., Khodzher T.V. et al. 1996. Composition of individual aerosol particles above Lake Baikal, Siberia. Atmospheric Environment 30: 1453-1465.

Vetrov V.A., Klimashevskaya Z.A. 1985. Monitoring of pollution of the land surface and Lake Baikal with inorganic components of emissions from Baikalsk Pulp and Paper Plant. In.: Israel Yu.A. (Ed.), Improvement of regional monitoring of Lake Baikal state. Leningrad: Hydrometeoizdat. (in Russian) 